\title{
Host and microbe determinants that may influence the success of $S$. aureus colonization
}

\author{
Mona Johannessen*, Johanna E. Sollid and Anne-Merethe Hanssen \\ Research Group of Host-Microbe Interaction, Department of Medical Biology, Faculty of Health Sciences, University of Tromsø, Tromsø, Norway
}

Edited by:

Francois Vandenesch, Immunity

Infection Vaccination, France

Reviewed by:

Ross Fitzgerald, Roslin Institute, UK Alex Van Belkum, bioMerieux, France

\section{*Correspondence:}

Mona Johannessen, Research Group of Host-Microbe Interaction, Department of Medical Biology, Faculty of Health Sciences, University of Tromsø, 9037 Tromsø, Norway. e-mail:mona.johannessen@uit.no

\begin{abstract}
Staphylococcus aureus may cause serious skin and soft tissue infections, deep abscesses, endocarditis, osteomyelitis, pneumonia, and sepsis. S. aureus persistently colonizes $25-$ $30 \%$ of the adult human population, and $S$. aureus carriers have an increased risk for infections caused by the bacterium. The major site of colonization is the nose, i.e., the vestibulum nasi, which is covered with ordinary skin and hair follicles. Several host and microbe determinants are assumed to be associated with colonization. These include the presence and expression level of bacterial adhesins, which can adhere to various proteins in the extracellular matrix or on the cellular surface of human skin. The host expresses several antimicrobial peptides and lipids. The level of $\beta$-defensin 3, free sphingosine, and cis-6hexadecenoic acid are found to be associated with nasal carriage of $S$. aureus. Other host factors are certain polymorphisms in Toll-like receptor 2, mannose-binding lectin, C-reactive protein, glucocorticoid-, and vitamin D receptor. Additional putative determinants for carriage include genetic variation and expression of microbial surface components recognizing adhesive matrix molecules and their interaction partners, as well as variation among humans in the ability of recognizing and responding appropriately to the bacteria. Moreover, the available microflora may influence the success of $S$. aureus colonization. In conclusion, colonization is a complex interplay between the bacteria and its host. Several bacterial and host factors are involved, and an increased molecular understanding of these are needed.
\end{abstract}

Keywords: Staphylococcus aureus, colonization, MSCRAMM, PAMP, PRR, immune evasion, microflora

\section{INTRODUCTION}

Human skin is easily accessible for microbial colonization and provides a wide variety of environmental conditions for growth. One of our most potent pathogens, Staphylococcus aureus, is a ubiquitous commensal that persistently colonizes $25-30 \%$ of the human population (Wertheim etal., 2004; van Belkum, 2011). $S$. aureus is the major cause of skin and soft tissue infections, and the bacteria can also infect any tissue of the body, causing other serious or life-threatening diseases, such as deep abscesses, endocarditis, osteomyelitis, and pneumonia. S. aureus is one of the most prevalent pathogens in bloodstream infections and effective treatment is a major clinical challenge. Emergence and spread of antimicrobial resistance combined with increasing numbers of immune-compromised patients make infections increasingly difficult to treat (Tong et al., 2012). Infection rates are higher in carriers of $S$. aureus than in non-carriers and invasive disease is often caused by the strain carried by the patient (von Eiff et al., 2001a; Wertheim et al., 2004). Eradication of nasal colonization with antibiotic treatment decreases the risk of post-operative infections (van Rijen et al., 2008), which may support an approach in which systemic $S$. aureus infections are prevented by eliminating or reducing nasal carriage.

Historically, individuals have been classified as non-carriers, intermittent carriers, or persistent carriers of S. aureus. However, non-carriers and intermittent carriers share similar nasal elimination kinetics and anti-staphylococcal antibody profiles.
Therefore, a reclassification of $S$. aureus nasal carriage is suggested and includes only two types of nasal carriers: persistent or others (van Belkum et al., 2009). The persistent carriage rate varies depending on age, gender, serum glucose level, smoking, oral contraceptive use, dialysis, and/or drug addiction (Kluytmans et al., 1997; Choi et al., 2006; Olsen et al., 2009; van Belkum, 2011). Various diseases are also associated with increased carriage rate, such as Wegener's granulomatosis patients with $63-72 \%$, atopic dermatitis (AD) patients with almost $100 \%$ and rheumatoid arthritis patients with 50\% carriage rate (Breuer et al., 2002; Laudien et al., 2010). Still, the success of $S$. aureus to colonize human nares remains an enigma. Since not all humans are persistent carriers and some bacterial clones are more common than others within a population, both human and microbial determinants seem to be involved. In this paper, we intend to review and discuss various parameters that may contribute to nasal carriage.

\section{STAPHYLOCOCCUS AUREUS COLONIZATION OF THE HUMAN HOST}

LOCALIZATION OF S. AUREUS

Staphylococcus aureus has been found in human nose, throat, perineum, and intestine (Wertheim et al., 2005; Mertz et al., 2007; Acton et al., 2009). However, as decolonization of the nose usually has a decolonizing effect on perineum, pharynx, and axillae as well, the nose is assumed to be the major site of $S$. aureus colonization (Kluytmans and Wertheim, 2005) although sole intestinal 
carriage also can occur (Acton et al., 2009). Sampling of the various areas inside the noses of healthy individuals revealed that $S$. aureus is mainly localized in the vestibulum nasi (Cole et al., 2001), and the bacterial load of two persistent carriers varied between $10^{4}$ and $10^{5}$ bacteria/nasal swab over time (Burian et al., 2010b).

Intracellular $S$. aureus have been found in biopsies from the anterior part of the middle turbinate or tonsils from patients with recurrent rhinosinusitis or tonsillitis, respectively (Clement et al., 2005; Zautner et al., 2010). The intracellular residency in epithelial cells was a significant risk factor for recurrent episodes of rhinosinusitis (Plouin-Gaudon et al., 2006). The intracellular localization of $S$. aureus is thought to be part of the pathophysiological mechanisms behind prolonged course, chronic, or frequent relapse of rhinosinusitis, osteomyelitis, mastitis, or endocarditis (Plouin-Gaudon et al., 2006; Garzoni and Kelley, 2009; Sinha and Fraunholz, 2010). S. aureus can be internalized by various cell types, such as endothelial cells, epithelial cells, fibroblasts, osteoblasts, and keratinocytes in addition to the professional phagocytes (Garzoni and Kelley, 2009). The invasiveness and survival of bacteria within the mammalian cells varies, and may depend on bacterial strain, ability to form small colony variant (SCV), multiplicity of infection (MOI) as well as the mammalian cell type. Prolonged survival of bacterial cells can result in release of viable bacterial cells when the host cell dies (von Eiff et al., 2001b; Krut et al., 2003; Garzoni and Kelley, 2009; Sinha and Fraunholz, 2010). Whether S. aureus can be found intracellular within keratinocytes during nasal colonization remains unknown, but $S$. aureus is rapidly invading the keratinocytes in skin biopsies taken from human hosts (Kisich et al., 2007).

\section{FEATURES OF THE COLONIZED TISSUE}

A histological study of human cadavers revealed bacteria in stratified squamous epithelium and hair follicle shafts in the nose (Ten Broeke-Smits et al., 2010). The outermost area in the nose is covered by ordinary skin, which is divided into two main structures: a layer of highly regenerating epidermis and dermis, which is drained by lymphatic and vascular conduits (Nestle et al., 2009). The dominating cell type in epidermis is keratinocytes, but also Langerhans cells, melanocytes, Merkel cells, and T cells are present (Nestle et al., 2009; Hari et al., 2010). The keratinocytes in the basal layer (stratum basale) express the basal keratins K5, K14, and K15. Through continuous proliferation, the basal layer provides cells that differentiate, move, and form the stratum spinosum. The postmitotic cells in stratum spinosum express suprabasal keratins $\mathrm{K} 1$ and $\mathrm{K} 10$, which reinforce mechanical strength of the layer. These cells continue to differentiate and form stratum granulosum. The keratinocytes in stratum granulosum contain lamellar bodies, which are secretory organelles that are unique to epidermis. In the terminal differentiation of keratinocytes, filaggrin aggregates the keratin filaments into tight bundles, promoting the collapse of the cells. The resulting multilayer of flattened, anucleated corneocytes is called stratum corneum or the cornified layer. Corneocytes contain a cornified envelope consisting of structural proteins such as involucrin, loricrin, trichohyalin, transglutaminases, and filaggrin in addition to keratin $\mathrm{K} 1$ and $\mathrm{K} 10$ providing mechanical strength. A complex series of lipids are covalently attached to the proteins of the cornified envelope. Moreover, the laminar bodies secrete hydrolytic enzymes as well as phospholipids, ceramides, glycosyl ceramides, and sterols, which can be further metabolized in the extracellular space (Proksch et al., 2008; Nestle et al., 2009). Additional lipids are provided by the sebaceous glands (Toth et al., 2011).

Almost all patients with $\mathrm{AD}$ are colonized with S. aureus (Breuer et al., 2002). Loss-of-function variants of the structural epidermal protein filaggrin are present in $9 \%$ of European population and are found to be predisposing factor for $\mathrm{AD}$ (Palmer et al., 2006). Individuals with loss-of-function filaggrin have significantly reduced natural moisturizing factor in stratum corneum and higher transepidermal water loss (Kezic et al., 2008). The components of natural moisturizing factor include urocanic acid (UCA) and pyrrolidone carboxylic acid (PCA), which in addition to hydration may also be involved in $\mathrm{pH}$ regulation of the skin. UCA and PCA are breakdown products from filaggrin. Physiological concentrations of these compounds reduce the growth rate of S. aureus as well as the expression of bacterial proteins involved in colonization and immune evasion. This suggests that colonization of individuals with loss-of-function mutations of filaggrin, which lacks the breakdown products in skin, may have a reduced ability to inhibit S. aureus growth (Miajlovic et al., 2010).

\section{BACTERIAL AND HOST PROTEINS INVOLVED IN ADHESION}

The adherence between $S$. aureus and the nasal epithelium is a multifactorial process that involves various interaction partners in both organisms. The primary bacterial adherence is thought to be mediated by wall teichoic acid (WTA), whereas sortaseanchored microbial surface components recognizing adhesive matrix molecules (MSCRAMMs) have critical roles at later stages of colonization of the human nose (Weidenmaier et al., 2008; Burian et al., 2010a). Detailed MSCRAMM-host interaction in vitro studies have revealed that $S$. aureus clumping factor B (ClfB) adheres to cytokeratin K10 (O'Brien et al., 2002; Wertheim et al., 2008; Clarke etal., 2009) and K8 (Haim et al., 2010). ClfB is expressed during nasal colonization and contributes to nasal colonization in humans (Wertheim et al., 2008; Burian et al., 2010b). However, ClfB-deficient cells of S. aureus strains 8325-4 and Newman could still interact with the nasal cells (O'Brien et al., 2002), which clearly demonstrate the utilization of several independent MSCRAMMs for colonization.

Another S. aureus adhesin that has shown interactions with harvested human desquamated epithelial cells is Iron-regulated surface determinant A (IsdA) (Clarke et al., 2006), which is also expressed during nasal colonization in humans (Burian et al., 2010b). The corneocyte envelope proteins loricrin and involucrin are identified as IsdA interaction partners (Clarke et al., 2009). The bacterial proteins SdrC, SdrD, and SasG are also shown to promote adhesion of bacteria to desquamated nasal epithelial cells harvested from human donors (Roche et al., 2003; Corrigan et al., 2009). Several other S. aureus MSCRAMMs or adhesins are identified, which interact with host molecules such as fibrinogen, elastin, collagen, or von Willebrand factor (Heilmann, 2011). However, the involvement of these factors in nasal colonization remains elusive. 
The panel of MSCRAMMs varies among S. aureus isolates (McCarthy and Lindsay, 2010). Interestingly, comparison of S. aureus 8325-4 and S. aureus 8325-4 (pKS80::sasG) showed that expression of SasG reduced S. aureus adherence to fibrinogen and fibronectin. Thus, certain MSCRAMMs might mask the adhesive functions of other adhesins, and possibly even change the tropism for the host cell (Roche et al., 2003). The individual combinations of MSCRAMMs may therefore influence the microbial success of adhesion. Also, allelic variations between bacterial adhesins of the same type may also either improve or reduce their binding to human cells. Moreover, there may be variations in expression level of MSCRAMMs. Different MSCRAMM expression profiles were, for example, observed for so-called carrier and non-carrier strains of $S$. aureus, where the carrier strain expressed a markedly larger number of adhesive proteins such as SasD and SdrH (Muthukrishnan et al., 2011).

Cells from different donors provide variable levels of adhesion to S. aureus (Aly et al., 1977; Weidenmaier et al., 2008). This may suggest that there are differences in the expression levels or different polymorphic variants of human interaction partner, which may influence the level of bacterial adhesion. Fibronectin and fibrinogen contribute to $S$. aureus binding. Fibronectin has been found in stratum corneum of $\mathrm{AD}$ skin, but not in healthy skin, which may partly explain the abundant colonization of atopic skin (Cho et al., 2001). Also, AD patients have an impaired proliferation and differentiation in both non-lesional and lesional skin, as seen by immunohistochemistry of Ki67 (a marker of cell proliferation; Scholzen and Gerdes, 2000), involucrin, loricrin, filaggrin, and the keratins K5, K6, K10, K16, and K17 (Jensen et al., 2004). Loricrin, involucrin, and K10 are interaction partners for $\mathrm{ClfB}$ and/or IsdA, and aberrant distribution of the interaction partners of these may be beneficial for colonization. Finally, there has also been found amino acid variation in elastin, fibrinogen/fibrin, fibronectin, prothrombin, vitronectin, and von Willebrand factor (McCarthy and Lindsay, 2010). Such an amino acid variation may also influence the risk of colonization.

All these studies suggest that the success of adhesion to host may depend on the correct combination and allelic variant of MSCRAMM together with the appropriate expression and variant of human host ligand.

\section{EXPRESSION OF COLONIZATION DETERMINANTS}

Burian et al. (2010b) addressed the expression of several S. aureus transcripts during nasal colonization of humans. The bacteria were found to express the adhesive molecules $(c l f \mathrm{~B}$, is $d \mathrm{~A}, f n b \mathrm{~A}$, atlA, eap, WTA), genes involved in cell surface dynamics/remodeling $(s c e \mathrm{D}, \operatorname{oat} \mathrm{A}$, atl $\mathrm{A})$ and immune-modulatory factors (sak, chp, $s p a$, eap) under these conditions. In contrast, the major toxins ( $h l a, p s m)$ were not transcribed during colonization of the human nose.

The environment in the nose may also require reactive oxygen species and desiccation tolerance. Alkyl hydroperoxide reductase $(A h p C)$ and catalase (katA), which engender increased $\mathrm{H}_{2} \mathrm{O}_{2}$ tolerance, were found to be associated with nasal carriage in a cotton rat model (Cosgrove et al., 2007), but their possible impact on colonization of the human nose is not known.

\section{INFLUENCE OF BIOFILM}

Biofilm and planktonic cultures of $S$. aureus have different impacts on gene expression in keratinocytes (Secor et al., 2011). In nasal secretion, a so-called carrier strain of $S$. aureus, but not a noncarrier strain, was surrounded by an additional electron-dense layer covering the peptidoglycan, which might represent the initial stages of biofilm formation (Cole et al., 2001; Quinn et al., 2009). This may provide resistance against phagocytosis and/or oxidative burst. Moreover, the carrier strain biofilm exoproteome contained a greater number of immunoevasive proteins than its planktonic counterpart (Muthukrishnan et al., 2011). However, a dispersed rather than biofilm-related mode of growth is thought to occur during S. aureus nasal colonization (Krismer and Peschel, 2011).

\section{THE INFLUENCE OF MICROFLORA ON S. AUREUS NASAL CARRIAGE}

The nares are colonized by a temporally stable microbiota distinct from other regions of the integument (Frank et al., 2010). The nasal microbiota of healthy adults has been shown to consist primarily of members of the phylum Actinobacteria (e.g., Propionibacterium spp. and Corynebacterium spp.), but also Firmicutes (e.g., Staphylococcus spp.) and Proteobacteria (e.g., Enterobacter spp.) (Frank et al., 2010; Wos-Oxley et al., 2010). Healthy adults harbor significantly more species-rich and diverse nares microbiotas than hospitalized individuals (Wos-Oxley et al., 2010).

Staphylococcus epidermidis is the most commonly isolated bacterial species from healthy human skin and may protect humans from pathogenic bacteria. S. epidermidis produce phenol-soluble modulins, which inhibit the growth of Streptococcus pyogenes. These modulins also induce lipid vesicle leakage and exert antimicrobial action against S. aureus (Cogen et al., 2010a,b). In addition, Lai et al. (2009) showed that the microflora can modulate specific cutaneous inflammatory responses and that a product of staphylococci, lipoteichoic acid (LTA), inhibits skin inflammation. Moreover, S. epidermidis LTA modulates the inflammation through a Toll-like receptor (TLR)-cross-talk phenomenon between TLR2 and TLR3. Finally, the presence of $S$. epidermidis has been shown to induce expression of human $\beta$-defensin 2 (hBD2) and human $\beta$ defensin 3 (hBD3) in keratinocytes, thereby inhibiting the growth of pathogenic organisms, e.g., S. aureus and group A streptococci (GAS) (Lai et al., 2010).

Staphylococcus aureus carriage has been shown to be negatively associated with a variety of other nares-associated microbial species, most significantly S. epidermidis and Propionibacterium acne (Frank et al., 2010). Bogaert et al. (2004) noted a negative correlation for co-colonization of $S$. aureus and vaccine-type pneumococci in the nasopharynx of children, but not for $S$. aureus and non-vaccine serotype pneumococci, suggesting that there might be a natural competition between colonization with vaccine-type pneumococci and S. aureus.

Uehara etal. (2000) reported a low incidence of S. aureus carriage in individuals who also were positive for Corynebacterium sp. by nose swabs suggesting competition for survival between S. aureus and corynebacteria. Lina et al. (2003) later showed that the $S$. aureus nasal colonization rate correlated negatively with the rate of colonization by Corynebacterium spp. and S. epidermidis, suggesting that both Corynebacterium spp. and 
S. epidermidis antagonize S. aureus colonization. Colonization by methicillin-resistant $S$. aureus (MRSA) agr-1Sa strains was specifically associated with a low rate of colonization by Corynebacterium spp. and agr-3Se S. epidermidis (Lina et al., 2003), thus suggesting a potential competitive interaction among different species with special emphasis on the influence of staphylococcal agr alleles.

Staphylococcus epidermidis may also "protect" the host from S. aureus colonization via quorum sensing cross-inhibition. Production of specific peptide pheromones affect agr signaling in competing bacteria, and thus lead to colonization inhibition of, e.g., S. aureus (Otto et al., 2001). A serine protease (Esp, $27 \mathrm{kDa}$ ) secreted by a subset of $S$. epidermidis can inhibit $S$. aureus biofilm formation and nasal colonization in vivo. S. epidermidis cells were introduced into the nasal cavities of volunteers who were $S$. aureus carriers. The wild-type S. epidermidis eliminated $S$. aureus colonization, but its isogenic esp mutant did not (Iwase et al., 2010).

The displacement of $S$. aureus by $S$. pneumoniae in the nasopharynx may be explained by $\mathrm{H}_{2} \mathrm{O}_{2}$-mediated bacterial interference. Hydrogen peroxide produced by $S$. pneumoniae kills lysogenic but not non-lysogenic staphylococci by inducing the SOS response. The SOS response induces resident prophages and thereby lysis and $\mathrm{H}_{2} \mathrm{O}_{2}$ lethality (Selva et al., 2009). It has also been shown that production of $\mathrm{H}_{2} \mathrm{O}_{2}$ by viridans group streptococci may inhibit MRSA colonization of oral cavities in newborns (Uehara et al., 2001). But in mixed-inoculum colonization experiments and experiments where $S$. aureus invaded the nasopharynx of rats with established $S$. pneumoniae populations, the density of $S$. aureus did not differ whether the $S$. pneumoniae strain was $\mathrm{H}_{2} \mathrm{O}_{2}$ secreting or non- $\mathrm{H}_{2} \mathrm{O}_{2}$ secreting (Margolis et al., 2010).

\section{HOST MOLECULES THAT MIGHT INFLUENCE S. AUREUS CARRIAGE}

Staphylococcus aureus colonizes the human nares in an area covered with ordinary skin supplemented with nasal secretions. Thus, host molecules that might influence $S$. aureus carriage should be constitutively expressed and/or induced in the skin or nasal secretions. In the following, the focus will be on antimicrobial molecules, various cytokines, and the signaling pathways involved in the induction of them. In addition, we will provide examples of known polymorphisms in the signal molecules and complement factors/regulators that may influence the host defense against colonization or infection against $S$. aureus. There will also be a brief discussion about the adaptive immune system and its contribution to host protection against $S$. aureus colonization.

\section{ANTIMICROBIAL MOLECULES AND COLONIZATION}

The epidermis contains several antimicrobial lipids, peptides, or proteins provided by keratinocytes, sebocytes, mast cells, and eccrine sweat glands and also by circulating neutrophils or natural killer cells that are recruited to the skin (Schauber and Gallo, 2009). The various antimicrobial molecules may act in synergy to prevent colonization (Proksch et al., 2008), and their individual or combined expression pattern may influence the colonization status of $S$. aureus.

\section{Lipids}

Lipids in epidermis that have antimicrobial activity against $S$. aureus are the fatty acids lauric acid, sapienic acid, oleic acid, palmitoleic acid, and cis-6-hexadecenoic acid (Wille and Kydonieus, 2003; Takigawa et al., 2005; Nakatsuji et al., 2009; Chen et al., 2011; Toth et al., 2011). Similarly, sphingoid bases are synthesized from ceramides, and have broad antibacterial and antifungal activities (Proksch et al., 2008). A reduction in free sphingosine and cis-6-hexadecenoic acid has been found to be associated with carriage of S. aureus among AD patients (Arikawa et al., 2002; Takigawa et al., 2005). However, whether this pattern is found among healthy carriers is unknown.

\section{Antimicrobial peptides/proteins}

Another important player in the first-line defense in skin are antimicrobial peptides (AMPs) or proteins (Yamasaki and Gallo, 2008; Wiesner and Vilcinskas, 2010). Production of AMPs may be constitutive or induced by inflammation or injury. The various tissues produce specific profiles of different AMPs, which may vary significantly depending on the physiological condition. AMPs have the ability to kill the pathogens directly, and also to initiate a host defense response by signaling via receptors resulting in production of chemokines and recruitment of immune cells (Yamasaki and Gallo, 2008; Wiesner and Vilcinskas, 2010). In the following, we intend to provide a few examples of AMPs and proteins, and describe what is known regarding them and colonization with S. aureus.

Human $\alpha$-defensins, also called human neutrophil peptides, include the peptides HNP 1-4 and HD 5-6. The former are expressed in neutrophils, while the latter two peptides are mainly expressed in Paneth cells in the small intestine. The human $\beta$ defensins (hBD1-4) are expressed in mucosa and epithelial cells (Yamasaki and Gallo, 2008; Wiesner and Vilcinskas, 2010). The $\beta$-defensins have been compared in their antimicrobial activity against $S$. aureus, and the most potent is $\beta$-defensin 3 followed by $\beta$-defensin 2 and $\beta$-defensin 1 (Midorikawa et al., 2003; Chen et al., 2005; Kisich et al., 2007). Keratinocytes have constitutive capacity to kill $S$. aureus, a phenomenon that is dependent on $\beta$-defensin 3 (Kisich et al., 2007). Comparisons of skin biopsies revealed that the levels of $\beta$-defensin 3 are similar between normal individuals and those with $\mathrm{AD}$. However, the $\mathrm{AD}$ patients have a reduced ability to mobilize $\beta$-defensin 3 onto the bacteria due to presence of Th2 cytokines (Kisich et al., 2008). Also, a higher induction of $\beta$-defensin 3 , but not $\beta$-defensin 2 , is associated with a better clinical course and outcome of $S$. aureus skin infections (Zanger et al., 2010). Moreover, the level of both constitutive and induced $\beta$-defensin 3 is lower in persistent $S$. aureus nasal carriers compared to non-carriers, suggesting that $\beta$-defensin 3 is a determinant for carriage (Zanger et al., 2011). All these studies show the importance of presence of $\beta$-defensin 3 in clearing of $S$. aureus in colonization and infection.

The expression level of defensins may be regulated at several stages. The genes encoding $\beta$-defensins are clustered in chromosome $8 \mathrm{p} 23.1$, which is a frequent site of genetic rearrangement, and copy numbers of defensin genes may therefore vary among individuals (Linzmeier et al., 1999). However, no associations between nasal carriage of $S$. aureus and copy number and/or sequence 
variations among HNP 1-3 or $\beta$-defensin 3 have been found (van Belkum et al., 2007; Fode et al., 2011). Both $\alpha$ - and $\beta$-defensins are secreted as proproteins, and post-translational processing is needed in order to create mature defensins (Yamasaki and Gallo, 2008). The defensins' processing enzymes in human skin are unknown, and whether the activity of these influence carriage status is also unknown.

Cathelicidin is another AMP that is important in skin. The protein is stored as a proprotein named hCAP18 in laminar bodies in keratinocytes and secreted into the spinous layer of epidermis, where local proteases process the protein into active peptide(s). Stratum corneum tryptic enzyme (SCTE) modifies the propeptide into LL-37 at the skin surface. Then, a combination of SCTE and stratum corneum chymotryptic protease (SCCE) may further process LL-37 into smaller peptides known as RK-31 and KS-30 (Yamasaki and Gallo, 2008). RK-31 and KS-30 have increased antimicrobial activity against $S$. aureus compared to LL37 (Murakami et al., 2004). Whether the level and/or function of SCTE/SCCE and/or level of the processed peptides are associated with nasal carriage is not known.

Vitamin D appears to promote with both innate and adaptive immunity. The active variant $1,25-(\mathrm{OH})_{2}-\mathrm{D}_{3}$ has been found to enhance the antimicrobial function against $S$. aureus in vitro (Schauber et al., 2007, 2008). The promoter of the antimicrobial proteins cathelicidin and $\beta$-defensin 2 have vitamin $\mathrm{D}$ responsive elements (VDREs) (Gombart et al., 2005), and 1,25-(OH) $-\mathrm{D}_{3}$ can induce cathelicidin and/or $\beta$-defensin 2 in isolated human keratinocytes, monocytes, neutrophils, and myeloid cells as well as in human skin biopsies (Wang et al., 2004; Gombart et al., 2005; Weber et al., 2005). Also, supplementation of oral vitamin D induced cathelicidin production in AD lesional skin (Hata et al., 2008). In addition to inducing AMP expression, 1,25- $(\mathrm{OH})_{2}-\mathrm{D}_{3}$ has been found to induce CD14 and TLR2 expression in keratinocytes (Schauber et al., 2007), which may result in increased ability to detect pathogens. Epidemiological studies suggest that polymorphism in vitamin $\mathrm{D}$ responsive genes might be associated with $S$. aureus carriage among type I diabetes patients (Panierakis et al., 2009), but not among a healthy, elderly populations (Claassen et al., 2005). There is also reported an association between vitamin D deficiency and MRSA nasal carriage (Matheson et al., 2010). Recently, we found that nasal carriage of S. aureus is associated with serum 25-hydroxyvitamin D level, gender, and smoking status (Olsen et al., 2011). All these studies suggest that the vitamin D protects against carriage of S. aureus, which may be due to, among other factors, increased expression of cathelicidin in the skin.

RNase 7 is an additional AMP found in stratum corneum. Lower RNase 7 expression in healthy skin is associated with increased risk for new onset of $S$. aureus skin infection (Zanger et al., 2009). However, no association was found between RNase 7 level and carriage of S. aureus (Zanger et al., 2011).

Finally, there are several other proteins that may have antimicrobial activity against $S$. aureus. Examples include dermcidin and histone $\mathrm{H} 4$, which are expressed in eccrine sweat glands and by sebocytes, respectively, and secreted to the skin (Rieg etal., 2004; Lee et al., 2009). Moreover, secretory leukocyte protease inhibitor (SLPI) and elafin/elastase-specific inhibitor (ESI)/skin-derived antileukoprotease (SKALP) kill S. aureus (Hiemstra et al., 1996; Simpson et al., 1999), and the proteins can be induced in keratinocytes/epidermis (Bando et al., 2007). Another class of putative relevant antimicrobial proteins is the peptidoglycan recognition proteins (PGRPs; Dziarski and Gupta, 2010). Furthermore, several cytokines and chemokines are found to have antimicrobial activity against $S$. aureus to various degrees: CXCL1/Gro $\alpha$, CXCL2/Gro $\beta$, CXCL3/Gro $\gamma$, CXCL9/MIG, CXCL10/IP-10, CXCL11/I-TAC, CXCL12/SDF-1, CXCL13/BCA-1, CXCL-14/BRAK, XCL1/lymphotactin, CCL1/I309, CCL11/eotaxin, CCL17/TARC, CCL18/PARC, CCL20/MIP3$\alpha$, CCL21/SLC, CCL22/MDC, CCL25/TECK, IL-1 $\alpha$, and IL-1 $\beta$ (Yang et al., 2003; Quinn et al., 2009). However whether the combination or expression level of any of the mentioned proteins influence carriage is unknown.

\section{Nasal secretion and its effectors}

Several proteins have been identified in nasal secretions, among them $\alpha$-defensin $1-2, \beta$-defensin $1-2$, lysozyme, lactoferrin, and hemoglobin (Cole et al., 1999; Pynnonen et al., 2011). Carriers of $S$. aureus have elevated levels of $\alpha$-defensins $1-3, \beta$-defensin 2 , lactoferrin, and $\operatorname{sg} \mathrm{A}$ in their nasal secretions (Cole et al., 2001; Kartashova etal., 2009). As $\alpha$-defensins 1-3 are expressed in neutrophils, the elevated level may indicate the presence and/or activation of neutrophils in nasal secretion or epidermis among carriers. However, this remains to be investigated. The presence of hemoglobin in nasal secretions was recently found to be another host determinant for $S$. aureus colonization. The mechanism may involve hemoglobin-mediated inhibition of the expression of the agr quorum sensing system (Pynnonen et al., 2011).

\section{THE HOST IMMUNITY AND S. AUREUS CARRIAGE}

Bacteria contain or may secrete substances that are recognized by the host as pathogen-associated molecular patterns (PAMPs). The bacterial cell wall of $S$. aureus is composed of multiple peptidoglycan layers in combination with WTAs, LTA, and various MSCRAMMs. Moreover, the bacteria secrete $N$-formylated methionine and/or other substances that can be recognized as PAMPs (Fournier and Philpott, 2005). The cells involved in the innate immune system express various pattern-recognition receptors (PRRs), which specifically recognize PAMPs (Figure 1). Among the PRRs known to be involved in recognizing $S$. aureus is the TLR2 in various combinations with TLR1 or TLR6 and/or CD36 and CD14 (Fournier and Philpott, 2005; Nilsen et al., 2008) as well as the intracellular nucleotide-binding and oligomerization domain (NOD)-like receptors (NLRs) NOD2 and NLRP3 (Fournier and Philpott, 2005; Craven et al., 2009). Activation of PRRs activates intracellular signaling resulting in altered gene expression (Figure 1). In addition, mannose-binding lectin (MBL) or ficollins may also bind to pathogens, thereby activating the complement system followed by opsonization and increased phagocytosis of the bacteria (Casanova and Abel, 2004).

\section{Signaling through TLR}

Toll-like receptor is a transmembrane glycoprotein, which consists of an extracellular domain, a transmembrane domain, and a cytoplasmic Toll/interleukin-1 receptor (TIR) domain. Ligand binding 


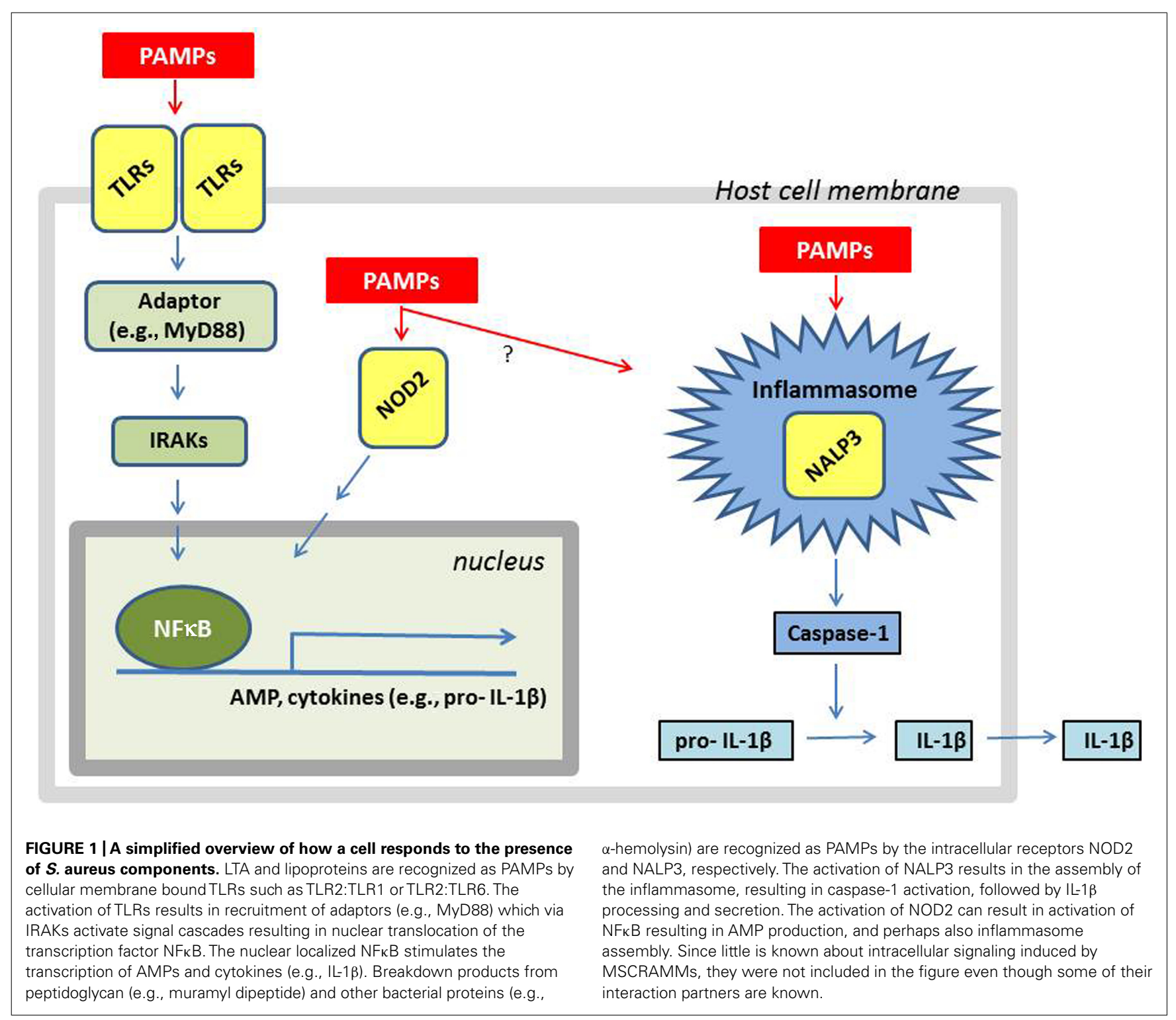

to TLRs results in recruitment of other TIR-containing proteins such as the adaptor protein myeloid differentiation primaryresponse protein 88 (MyD88), TIR-domain-containing adaptor protein (TIRAP), TIPAP-inducing interferon (IFN)- $\beta$ (TRIF) or TRIF-related adaptor molecule (TRAM). This initiates a signaling cascade involving IL-1R-associated kinases (IRAKs) and other kinases, which activates mitogen-activated kinases (MAPKs) and transcription factors such as nuclear factor $\kappa \mathrm{B}(\mathrm{NF} \kappa \mathrm{B})$ and IFNregulatory factors (IRFs). The final result of the activation of the cascade is increased expression and secretion of various AMPs, cytokines, and chemokines, thereby recruiting immune cells to the site of infection and triggering of the adaptive immune response (Akira and Takeda, 2004; Kumar et al., 2009).

Subcutaneous inoculation of S. aureus into TLR2-, MyD88-, and IL-1R-deficient mice revealed that IL-1R/MyD88 signaling in resident skin cells were of particular importance in neutrophil recruitment to the site of infection (Miller et al., 2006). IL-1R ligands include IL- $1 \alpha$ and IL-1 $\beta$. Studies in mice showed that bone marrow cell-derived IL- $1 \beta$, but not IL- $1 \alpha$, was found to be important for IL-1R-induced neutrophil recruitment against cutaneous S. aureus challenge in vivo (Miller et al., 2007). In humans, treatment of rheumatoid arthritis with IL-1 receptor antagonists results in increased susceptibility to $S$. aureus infections (Miller and Cho, 2011), but whether IL-1 receptor signaling is of importance in protecting against colonization is not known.

Autosomal recessive MyD88- and IRAK4-deficient humans have been identified. The patients have a predisposition to severe bacterial infections, and $S$. aureus was the cause of invasive infection in 14 and 20\% of IRAK4- and MyD88-deficient patients, respectively. The patients also had recurrent, localized skin infections often caused by S. aureus (Picard et al., 2011).

The above-mentioned knock-out studies in mice as well as the autosomal recessive MyD88 and IRAK-4 patients demonstrate 
that TLR2 and MyD88 are of importance in protecting against S. aureus. Epidemiological studies show no or little association between TLR2 R753Q and/or the GT repeat and severe S. aureus infection (Lorenz et al., 2000; Moore et al., 2004); however, an association between a TLR2 R753Q polymorphism and nasopharyngeal $S$. aureus carriage among healthy infants was recently found (Vuononvirta et al., 2011). Also, among AD patients, which are often colonized with the bacteria, 9 out of 78 patients $(11.5 \%)$ carried the TLR2 R753Q variant (Ahmad-Nejad et al., 2004). Only a few studies in mice have addressed the involvement of TLR2, IL$1 \mathrm{R}$, or MyD88 in nasal carriage of S. aureus. However, inoculation of $S$. aureus COL into the nasal cavity of TLR2 and TLR4 knockout mice showed that TLR2 was important for the early innate immune response in the mice, while no significant differences in colony forming units were found between mice 7 days after inoculation (González-Zorn et al., 2005).

Toll-like receptor signaling can also be influenced by ligandbound glucocorticoid receptor (GR), resulting in reduction in the expression of pro-inflammatory cytokines and up-regulation of anti-inflammatory cytokines (Moynagh, 2003). There are multiple isoforms of GR arising from alternative splicing and translational events of the single gene and various polymorphic variants exist (Tait et al., 2008). The exon $9 \beta$ and ER22/23EK polymorphisms were found to be associated with a $68 \%$ decreased and $80 \%$ increased risk of $S$. aureus nasal carriage, respectively (van den Akker et al., 2006). The most common glucocorticoid found in human is cortisol. However, no differences were found in the long-term cortisol level among carriers and non-carriers of the bacteria (Manenschijn et al., 2011).

\section{Signaling through NLR}

The NLRs are divided into three subfamilies: NALPs, IPAF/NAIP, and NODs. Most NLRs are expressed in the cytosol. NALP1, -2, and -3 are central in creating a PAMP-induced caspase- 1 activating complex called the inflammasome, which catalyzes the cleavage of pro-IL- $1 \beta$ and pro-IL-18 into IL- $1 \beta$ and IL-18. The full activation of inflammasomes is tightly regulated and can be divided in two steps. First, it is primed by the TLR-mediated up-regulation of expression of pro-IL-1 $\beta$ and other proteins involved in formation of the inflammasome. A second signal is needed for the assembly of the inflammasome (Martinon et al., 2009; Gross et al., 2011). The formation of NALP3 inflammasome can be induced by for instance $S$. aureus $\alpha$-hemolysins resulting in IL- $1 \beta$ secretion (Craven et al., 2009).

NOD2 is expressed in skin and in keratinocytes, and recognize peptidoglycan fragments, e.g., muramyl dipeptide, resulting in increased expression of $\beta$-defensin 2 and various cytokines (Voss et al., 2006; Siod and Fløisand, 2009). Also, NOD2 has been suggested to play a role in the activation of some types of inflammasomes (Martinon et al., 2009). NOD2-deficient mice are highly susceptible to $S$. aureus infection, and show highly decreased survival after injection with living S. aureus (Takeuchi et al., 2000; Deshmukh et al., 2009). Similarly, NOD2-deficient mice subcutaneously injected with $S$. aureus have reduced ability to clear $S$. aureus compared with wild-type mice. The neutrophil recruitment to the skin, as well as serum IgG titers, did not differ between wild-type and NOD2-deficient mice, suggesting that NOD2 is dispensable for normal induction of an adaptive immune response against the bacteria. Instead, NOD2 was required for caspase1 -released IL-1 $\beta$ which induced IL- 6 production and increased the neutrophil-mediated killing of $S$. aureus in the skin (Hruz et al., 2009).

NOD2 mutations have been associated with Crohn's disease, and some of the resulting NOD2 proteins were less capable of responding to the bacterial ligand muramyl dipeptide (Turvey and Broide, 2010). Neutrophil dysfunction and increased survival of S. aureus have been reported in these patients (Hruz et al., 2009 and references therein). However, even though the NLR pathway is of importance in clearing skin infections caused by $S$. aureus, it remains elusive whether the pathway is of importance in determining nasal carriage status.

\section{The complement system}

The main function of the complement system is to promote inflammation, opsonization and lysis of microorganisms, and to remove immune complexes. The complement system consists of a variety of serum proteins that can be activated by microorganisms by three different routes, the classical pathway, the lectin pathway, and the alternative pathway. The classical pathway is activated by $\mathrm{C1q}$ binding to antibodies localized on the surface of the bacteria. The lectin pathway is activated when proteins such as MBL attach to the carbohydrate on the bacteria thereby recruiting the MBL-associated serine proteases (MASPs), while the alternative pathway is activated when $\mathrm{C} 3 \mathrm{~b}$ covalently binds to a microbe. The activation of any of these pathways results in activation of $\mathrm{C} 3$, resulting in production of the anaphylatoxin $\mathrm{C} 3 \mathrm{a}$ and the opsonin C3b. The assembly of C5 convertases occurs, resulting in the production of anaphylatoxin C5a, as well as C5b and C6-C9, resulting in the production of the lytic membrane-attack complex (MAC) which may lyse the microorganism (Kemper and Atkinson, 2007). The complement system is highly regulated. The regulators of complement activation (RCA) include various proteins, as for example factor $\mathrm{H}$, which acts to destabilize the $\mathrm{C} 3$ convertase or promote the factor I-mediated cleavage of $\mathrm{C} 3 \mathrm{~b}$ into iC3b (Lambris et al., 2008). Another important RCA is the serine protease $\mathrm{C} 1$ inhibitor, which regulates both the classical and MBL pathway by inhibiting C1s/C1r and MASP-1/MASP-2, respectively (Zeerleder, 2011).

Mannose-binding lectin is a liver-produced circulating plasma homomultimer complex. Three common polymorphisms are found in exon 1 (R52C, G54D, and G57E), which interfere with the oligomerization ability of the polypeptide. The mutations result in $\mathrm{D}, \mathrm{B}$, and $\mathrm{C}$ alleles, respectively, while the wild-type allele is named A. The B and C variants occur in $22-28$ and $50-60 \%$ of Eurasian and sub-Saharan African populations, respectively, while the D variant reaches frequencies of $14 \%$ in European populations. In addition, there are two common polymorphisms also identified in the upstream promoter region, which determine serum levels by regulating protein expression. Therefore, the level of functional MBL in serum differs among human population due to a high frequency of various polymorphisms in different combinations. Still, the level is relatively constant within the individual and increases only two- to threefold upon infectious or inflammatory challenge (Turner, 2003; Ip et al., 2009). 
Mannose-binding lectin is produced at the nasal mucous lining, and wild-type $\mathrm{MBL}$ haplotype $\mathrm{A}$ is associated with carriage (van Belkum et al., 2007), while the nasopharyngeal bacterial colonization rates were significantly higher in infants with the variant types B, C, and D of MBL (Vuononvirta et al., 2011). MBL is involved in opsonophagocytosis, and found to interfere with TLR2/TLR6mediated signaling and expression of cytokines in professional phagocytes (Turner, 2003; Ip et al., 2009), but it is not known whether the variants of MBL differently influence these functions. Another protein that influences complement activation is the acute phase protein C-reactive protein (CRP). Single nucleotide polymorphisms (SNPs) found in CRP include C1184T (rs1130864), C2042T (rs1205), and C2911G (rs3093068). The individual SNPs are not associated with $S$. aureus carriage, but the CRP haplotype 1184C, 2042C, and 2911C were overrepresented in non-carriers in a large cohort (Emonts et al., 2008). A challenge in finding SNPs associated with carriage is the huge heterogeneous genetic background between individuals. One group investigated nasal carriage among 154 adult Wayampi Amerindians living in an isolated village in the Amazonian forest. The SNPs CRP C2042T and C1184 were found to be significantly associated with persistent carriage in this population (Ruimy et al., 2010).

Various bacteria circumvent the complement activation by various mechanisms, including recruiting complement regulators to its surface (Laarman et al., 2010). Recently, S. aureus was found to recruit the complement regulator factor $\mathrm{H}$, which via factor I mediated cleavage of C3b, evaded the alternative pathway (Sharp and Cunnion, 2010). Polymorphisms in factor $\mathrm{H}$ may influence its expression, or the ability to interact with Sbi or other S. aureusderived proteins. So far, only the $\mathrm{Y} 402 \mathrm{H}$ variant of factor $\mathrm{H}$ has been tested in epidemiological studies and found not to be associated with nasal carriage of $S$. aureus, but instead with occurrence of boils (Emonts et al., 2008). Another complement regulator is the serine protease C1 inhibitor. An SNP in position 480, replacing a valine with a methionine, has been found to be associated with $S$. aureus carriage, and the V/V genotype was significantly overrepresented in non-carriers (Emonts et al., 2007). Taken together, some association between certain polymorphisms in complement genes and nasal carriage of $S$. aureus have been found, but the molecular mechanisms behind these remains to be investigated.

\section{Professional phagocytes}

The presence of $S$. aureus results in increased levels of various AMPs, but also cytokines, chemokines, formylated methioninecontaining proteins and complement which all contribute to neutrophil rolling, adhesion, diapedesis, and thereby recruitment of the neutrophils into the skin. The phagocytes engulf the bacteria, and kill them by generating reactive oxygen and nitrogen species, various AMPs, proteinases, and acid hydrolases (Foster, 2005; Miller and Cho, 2011). In addition, neutrophils may try to defend the host against the bacteria by creating extracellular traps, which prevent the microbe from spreading and ensure a high local concentration of antimicrobial agents (Brinkmann et al., 2004).

AIDS patients suffer from impaired phagocytosis of $S$. aureus by granulocytes and monocytes. Defects in neutrophil differentiation, migration, or in ability to create a respiratory burst caused by other diseases might also influence $S$. aureus survival (Bouma et al., 2010; Miller and Cho, 2011). Chronic granulomatous disease patients, for example, have a defect in either of the proteins creating NADPH oxidase complex in phagocytes, and have recurrent bacterial infections which often are caused by $S$. aureus (Miller and Cho, 2011). The nasal secretion among persistent carriers contained the neutrophil specific $\alpha$-defensins $1-3$. Light microscope analysis of Wright-stained nasal fluid confirmed the presence of neutrophils in donor fluid from carrier and acute rhinitis patients, but not in fluid from normal donors (Cole et al., 2001). However, whether these cells had a disturbed ability to clear bacteria was not addressed.

\section{Carriage of $\boldsymbol{S}$. aureus and adaptive immunity}

Several studies have addressed whether human carriers have elevated levels of antibodies against $S$. aureus antigens compared to non-carriers. Many of these studies reveal that carriers have antibodies against various S. aureus antigens (Holtfreter et al., 2006; Wertheim et al., 2008; Verkaik et al., 2009a; Colque-Navarro et al., 2010). This may be one of several explanations of why human nasal carriers of $S$. aureus have some degree of protection against fatalities caused by infection (Holtfreter et al., 2006).

One could ask whether the elevated level of antibodies in carriers is caused by nasal colonization as such or by minor $S$. aureus infections due to scratches in the skin, etc. This question was recently addressed, and it was found that even though certain nonenterotoxin superantigens are expressed during nasal colonization, they did not induce systemic neutralizing antibodies. This suggests that nasal colonization of intact epithelium is not sufficient for the induction of a strong serum antibody response (Burian et al., 2012). Similarly, artificial colonization of adult volunteers with a laboratory strain of $S$. aureus did not elicit significant changes in the existing antibody repertoire (Broker and van Belkum, 2011). These studies may suggest that elevated levels of antibodies in carriers are not due to colonization per se.

It has also been questioned whether immunization can prevent colonization. Immunization studies in mice or cotton rats using IsdA, Isd H, or ClfB showed that immunization protected or reduced the level of S. aureus colonization (Clarke et al., 2006; Schaffer et al., 2006). However, young children with placental transfer of maternal IgG against S. aureus antigens were not protected against colonization (Verkaik et al., 2009b; Broker and van Belkum, 2011). More investigations are needed in order to finally state whether immunization can be used to prevent colonization.

\section{Th17 and cutaneous $S$. aureus}

Differentiation of CD4 ${ }^{+}$T cells yields the Thelper cells (Th) Th1-, Th2-, Th17-, and the regulatory $\mathrm{T}$ cell (Treg). The signature cytokines of Th17 are IL-17A and IL-17F, but the cells can also produce IL-21 and IL-22. The differentiation of CD4 ${ }^{+} \mathrm{T}$ cells into Th17 cells is dependent on cytokines such as IL-1 $\beta$, IL-6, and IL-23. The presence of these results in activation of JAK-STAT signaling pathway, which in turn stimulates the differentiation and production of the signature cytokines (Minegishi and Karasuyama, 2009; Ochs et al., 2009).

Several patients with hyper-IgE syndrome (HIES), or Job's syndrome, have mutations in STAT3 thereby resulting in reduced ability of T cells to differentiate into Th17 cells. These patients suffer 
from recurrent skin and pulmonary infections, often caused by S. aureus. $\mathrm{AD}$ and $\mathrm{HIV}$ patients are also predisposed to $S$. aureus cutaneous infections, which may be due to decreased Th17 cell responses and/or $\mathrm{CD}^{+}$cell counts. Similarly, individuals with autoantibodies against Th17-derived cytokines suffer from Candida infections and S. aureus skin infections. Studies from mice confirm that IL-17F and IL-17A are involved in host defense against S. aureus skin infection (Miller and Cho, 2011). However, whether or how these T cells influence nasal colonization is not known.

\section{STRAIN-DEPENDENT INFLUENCE ON HOST CYTOKINE RESPONSE}

The genome of $S$. aureus consists of a conserved core part and variable parts (Witney et al., 2005; McCarthy and Lindsay, 2010). The population structures of the nasal S. aureus isolates clearly illustrate diversity that can be clustered in various groups (Melles et al., 2004; Sakwinska et al., 2009; Sangvik et al., 2011). It is also debated whether certain clusters, subclusters, or strains are more virulent or better colonizers than others (Feil et al., 2003; Melles et al., 2004; Lindsay et al., 2006; Muthukrishnan et al., 2011).

A few studies have compared the various $S$. aureus strains in their ability to influence the expression of cytokines and AMPs. Although the molecular mechanisms remain elusive, 10 heat-inactivated clinical isolates varied in their ability to induce $\beta$-defensin 1, $\beta$-defensin 2, CAP18, and $\beta$-defensin 3 in human primary keratinocytes (Midorikawa et al., 2003). Also, comparisons of so-called carrier and non-carrier strains of S. aureus showed that they varied in their ability to interfere with expression of TLR2, $\beta$-defensin 3, IL- $1 \alpha$, IL-1 $\beta$, and IL-1Ra in nasal epithelial cell cultures (Quinn and Cole, 2007; Quinn et al., 2009). The strains also varied in their ability to form biofilms, and in sensitivity to IL- $1 \alpha$-mediated growth inhibition (Quinn et al., 2009). Studies in human umbilical vein endothelial cells have shown that the various $S$. aureus strains are equally invasive, while they differed greatly in their ability to induce inflammation perhaps depending on presence/absence of the agr (Grundmeier et al., 2010). Another putative mechanism affecting influence on cytokine expression is presence or absence of $\beta$-hemolysin in the $S$. aureus strains, as $\beta$-hemolysin is shown to influence endothelial IL- 8 expression (Tajima et al., 2007, 2009). All these studies indicate that the cellular response may vary depending on the $S$. aureus strain, which may influence the success for colonization of a particular strain.

\section{REFERENCES}

Acton, D. S., Plat-Sinnige, M. J., van Wamel, W., de Groot, N., and van Belkum, A. (2009). Intestinal carriage of Staphylococcus aureus: how does its frequency compare with that of nasal carriage and what is its clinical impact? Eur. J. Clin. Microbiol. Infect. Dis. 28, 115-127.

Ahmad-Nejad, P., Mrabet-Dahbi, S., Breuer, K., Klotz, M., Werfel, T., Herz, U., Neumaier, M., and Renz, H. (2004). The toll-like receptor 2 R753Q polymorphism defines a subgroup of patients with atopic dermatitis having severe phenotype. J. Allergy Clin. Immunol. 113, 565-567.
Akira, S., and Takeda, K. (2004). Tolllike receptor signalling. Nat. Rev. Immunol. 4, 499-511.

Aly, R., Shinefield, H. I., Strauss, W. G., and Maibach, H. I. (1977). Bacterial adherence to nasal mucosal cells. Infect. Immun. 17, 546-549.

Arikawa, J., Ishibashi, M., Kawashima, M., Takagi, Y., Ichikawa, Y., and Imokawa, G. (2002). Decreased levels of sphingosine, a natural antimicrobial agent, may be associated with vulnerability of the stratum corneum from patients with atopic dermatitis to colonization by Staphylococcus aureus. J. Invest. Dermatol. 119, 433-439.

\section{CONCLUSION}

Persistent nasal carriage of $S$. aureus is a complicated interplay between host and bacteria. In order to persistently colonize a human host, $S$. aureus must adhere to the skin and avoid being eliminated due to the human immune response. Presence or expression of appropriate MSCRAMMs and immune evasion molecules are needed for successful colonization. Moreover, the microflora in the nasal cavity influences the ability of $S$. aureus to colonize. The adhesion involves correct combinations and expression levels of bacterial adhesins and corresponding host interaction partners. Persistent carriers may have reduced expression levels of other antimicrobial molecules and/or a less efficient combination of these on the skin. Indeed, lower expression of $\beta$ defensin 3 is found to be associated with carriage. Another option is that the persistent carriers have polymorphic variants of the antimicrobial molecules, or enzymes involved in making these, resulting in less efficient molecules or reduced amounts of the antimicrobial molecules, respectively.

Nasal secretions among carriers reveal presence of certain AMPs including the neutrophil-derived HNPs. This may indicate $S$. aureus-mediated activation of the immune system, but without eliminating the bacteria. The molecular mechanisms behind this phenomenon remain to be investigated. Keratinocytes and immune cells also express various PRRs. Activation of these may result in production of antimicrobial molecules and/or production of various cytokines. Polymorphic variants of PRRs may interfere with their ability to detect PAMPs and thereby the host response. Similarly, as activation of PRR may result in activation in signaling pathways resulting in an altered gene response, polymorphic variants in any of these molecules may interfere with the ability of the host to respond to the presence of the bacteria.

Future studies will provide further knowledge regarding host and bacterial determinants involved in colonization. S. aureus colonization is an important risk factor for infection. By identifying determinants involved in colonization, putative molecules inhibiting colonization may be produced, which again will lead to reduced risk of infection by the endogenous $S$. aureus.

\section{ACKNOWLEDGMENTS}

Our work is supported by grants from the Norwegian Research Council, the Norwegian Regional Health Authority (Helse Nord RHF) and the Odd Berg Foundation.

Bando, M., Hiroshima, Y., Kataoka, M., Shinohara, Y., Herzberg, M. C., Ross, K. F., Nagata, T., and Kido, J. (2007). Interleukin-1alpha regulates antimicrobial peptide expression in human keratinocytes. Immunol. Cell Biol. 85, 532-537.

Bogaert, D., van Belkum, A., Sluijter, M., Luijendijk, A., de Groot, R., Rumke, H. C., Verbrugh, H. A., and Hermans, P. W. (2004). Colonisation by Streptococcus pneumoniae and Staphylococcus aureus in healthy children. Lancet 363, 1871-1872.

Bouma, G., Ancliff, P. J., Thrasher, A. J., and Burns, S. O. (2010). Recent advances in the understanding of genetic defects of neutrophil number and function. Br. J. Haematol. 151, 312-326.

Breuer, K., Haussler, S., Kapp, A., and Werfel, T. (2002). Staphylococcus aureus: colonizing features and influence of an antibacterial treatment in adults with atopic dermatitis. $\mathrm{Br}$. $\mathrm{J}$. Dermatol. 147, 55-61.

Brinkmann, V., Reichard, U., Goosmann, C., Fauler, B., Uhlemann, Y., Weiss, D. S., Weinrauch, Y., and Zychlinsky, A. (2004). Neutrophil extracellular traps kill bacteria. Science 303, 1532-1535.

Broker, B. M., and van Belkum, A. (2011). Immune proteomics of 
Staphylococcus aureus. Proteomics 11, 3221-3231.

Burian, M., Grumann, D., Holtfreter, S., Wolz, C., Goerke, C., and Broker, B. M. (2012). Expression of staphylococcal superantigens during nasal colonization is not sufficient to induce a systemic neutralizing antibody response in humans. Eur. J. Clin. Microbiol. Infect. Dis. 31, 251-256.

Burian, M., Rautenberg, M., Kohler, T., Fritz, M., Krismer, B., Unger, C., Hoffmann, W. H., Peschel, A., Wolz, C., and Goerke, C. (2010a). Temporal expression of adhesion factors and activity of global regulators during establishment of Staphylococcus aureus nasal colonization. J. Infect. Dis. 201, 1414-1421.

Burian, M., Wolz, C., and Goerke, C. (2010b). Regulatory adaptation of Staphylococcus aureus during nasal colonization of humans. PLOS ONE 5, e10040. doi: 10.1371/journal.pone. 0010040

Casanova, J. L., and Abel, L. (2004). Human mannose-binding lectin in immunity: friend, foe, or both? J. Exp. Med. 199, 1295-1299.

Chen, C. H., Wang, Y., Nakatsuji, T., Liu, Y. T., Zouboulis, C., Gallo, R., Zhang, L., Hsieh, M. F., and Huang, C. M. (2011). An innate bactericidal oleic acid effective against skin infection of methicillin-resistant Staphylococcus aureus: a therapy concordant with evolutionary medicine. J. Microbiol. Biotechnol. 21, 391-399.

Chen, X., Niyonsaba, F., Ushio, H., Okuda, D., Nagaoka, I., Ikeda, S., Okumura, K., and Ogawa, H. (2005). Synergistic effect of antibacterial agents human beta-defensins, cathelicidin LL-37 and lysozyme against Staphylococcus aureus and Escherichia coli. J. Dermatol. Sci. 40, 123-132.

Cho, S. H., Strickland, I., Boguniewicz, M., and Leung, D. Y. (2001). Fibronectin and fibrinogen contribute to the enhanced binding of Staphylococcus aureus to atopic skin. J. Allergy Clin. Immunol. 108, 269-274.

Choi, C. S., Yin, C. S., Bakar, A. A., Sakewi, Z., Naing, N. N., Jamal, F., and Othman, N. (2006). Nasal carriage of Staphylococcus aureus among healthy adults. J. Microbiol. Immunol. Infect. 39, 458-464.

Claassen, M., Nouwen, J., Fang, Y., Ott, A., Verbrugh, H., Hofman, A., van Belkum, A., and Uitterlinden, A. (2005). Staphylococcus aureus nasal carriage is not associated with known polymorphism in the vitamin $\mathrm{D}$ receptor gene. FEMS Immunol. Med. Microbiol. 43, 173-176.
Clarke, S. R., Andre, G., Walsh, E. J., Dufrene, Y. F., Foster, T. J., and Foster, S. J. (2009). Iron-regulated surface determinant protein A mediates adhesion of Staphylococcus aureus to human corneocyte envelope proteins. Infect. Immun. 77, 2408-2416.

Clarke, S. R., Brummell, K. J., Horsburgh, M. J., McDowell, P. W., Mohamad, S. A., Stapleton, M. R., Acevedo, J., Read, R. C., Day, N. P., Peacock, S. J., Mond, J. J., Kokai-Kun, J. F., and Foster, S. J. (2006). Identification of in vivo-expressed antigens of Staphylococcus aureus and their use in vaccinations for protection against nasal carriage. J. Infect. Dis. 193, 1098-1108.

Clement, S., Vaudaux, P., Francois, P., Schrenzel, J., Huggler, E., Kampf, S., Chaponnier, C., Lew, D., and Lacroix, J. S. (2005). Evidence of an intracellular reservoir in the nasal mucosa of patients with recurrent Staphylococcus aureus rhinosinusitis. J. Infect. Dis. 192, 1023-1028.

Cogen, A. L., Yamasaki, K., Muto, J., Sanchez, K. M., Crotty, A. L., Tanios, J., Lai, Y., Kim, J. E., Nizet, V., and Gallo, R. L. (2010a). Staphylococcus epidermidis antimicrobial delta-toxin (phenol-soluble modulin-gamma) cooperates with host antimicrobial peptides to kill group A Streptococcus. PLoS ONE 5, e8557. doi: 10.1371/journal.pone. 0008557

Cogen, A. L., Yamasaki, K., Sanchez, K. M., Dorschner, R. A., Lai, Y., MacLeod, D. T., Torpey, N. W., Otto, M., Nizet, V., Kim, J. E., and Gallo, R. L. (2010b). Selective antimicrobial action is provided by phenol-soluble modulins derived from Staphylococcus epidermidis, a normal resident of the skin. J. Invest. Dermatol. 130, 192-200.

Cole, A. M., Dewan, P., and Ganz, T. (1999). Innate antimicrobial activity of nasal secretions. Infect. Immun. 67, 3267-3275.

Cole, A. M., Tahk, S., Oren, A., Yoshioka, D., Kim, Y. H., Park, A., and Ganz, T. (2001). Determinants of Staphylococcus aureus nasal carriage. Clin. Diagn. Lab. Immunol. 8, 1064-1069.

Colque-Navarro, P., Jacobsson, G., Andersson, R., Flock, J. I., and Mollby, R. (2010). Antibody levels against eleven Staphylococcus aureus antigens in a healthy population. Clin. Vaccine Immunol. 17, 1117-1123.

Corrigan, R. M., Miajlovic, H., and Foster, T. J. (2009). Surface proteins that promote adherence of Staphylococcus aureus to human desquamated nasal epithelial cells. BMC Microbiol. 9, 22. doi: 10.1186/1471-2180-9-22
Cosgrove, K., Coutts, G., Jonsson, I. M., Tarkowski, A., Kokai-Kun, J. F., Mond, J. J., and Foster, S. J. (2007) Catalase (KatA) and alkyl hydroperoxide reductase (AhpC) have compensatory roles in peroxide stress resistance and are required for survival, persistence, and nasal colonization in Staphylococcus aureus. J. Bacteriol. 189, 1025-1035.

Craven, R. R., Gao, X., Allen, I. C., Gris, D., Bubeck, W. J., ElvaniaTekippe, E., Ting, J. P., and Duncan, J. A. (2009). Staphylococcus aureus $\alpha$-hemolysin activates the NLRP3inflammasome in human and mouse monocytic cells. PLoS ONE 4, e7446. doi: 10.1371/journal.pone.0007446

Deshmukh, H. S., Hamburger, J. B., Ahn, S. H., McCafferty, D. G., Yang, S. R., and Fowler, V. G. Jr. (2009). Critical role of NOD2 in regulating the immune response to Staphylococcus aureus. Infect. Immun. 77, 1376-1382.

Dziarski, R., and Gupta, D. (2010). Review: mammalian peptidoglycan recognition proteins (PGRPs) in innate immunity. Innate Immun. 16, 168-174.

Emonts, M., de Jongh, C. E., HouwingDuistermaat, J. J., van Leeuwen, W. B., de Groot, R., Verbrugh, H. A., Hermans, P. W., and van Belkum, A. (2007). Association between nasal carriage of Staphylococcus aureus and the human complement cascade activator serine protease $\mathrm{Cl}$ inhibitor (C1INH) valine vs. methionine polymorphism at amino acid position 480. FEMS Immunol. Med. Microbiol. $50,330-332$

Emonts, M., Uitterlinden, A. G., Nouwen, J. L., Kardys, I., Maat, M. P., Melles, D. C., Witteman, J., Jong, P. T., Verbrugh, H. A., Hofman, A., Hermans, P. W., and van Belkum, A. (2008). Host polymorphisms in interleukin 4, complement factor $\mathrm{H}$, and C-reactive protein associated with nasal carriage of Staphylococcus aureus and occurrence of boils. J. Infect. Dis. 197, 1244-1253.

Feil, E. J., Cooper, J. E., Grundmann, H., Robinson, D. A., Enright, M. C., Berendt, T., Peacock, S. J., Smith, J. M., Murphy, M., Spratt, B. G., Moore, C. E., and Day, N. P. (2003). How clonal is Staphylococcus aureus? J. Bacteriol. 185, 3307-3316.

Fode, P., Stegger, M., and Andersen, P. S. (2011). Human beta-defensin 3 (DEFB103) and its influence on Staphylococcus aureus nasal carriage. Int. J. Infect. Dis. 15, e388-e394.

Foster, T. J. (2005). Immune evasion by staphylococci. Nat. Rev. Microbiol. 3, 948-958.
Fournier, B., and Philpott, D. J. (2005). Recognition of Staphylococcus aureus by the innate immune system. Clin. Microbiol. Rev. 18, 521-540.

Frank, D. N., Feazel, L. M., Bessesen, M. T., Price, C. S., Janoff, E. N., and Pace, N. R. (2010). The human nasal microbiota and Staphylococcus aureus carriage. PLoS ONE 5, e10598. doi: 10.1371/journal.pone.0010598

Garzoni, C., and Kelley, W. L. (2009). Staphylococcus aureus: new evidence for intracellular persistence. Trends Microbiol. 17, 59-65.

Gombart, A. F., Borregaard, N., and Koeffler, H. P. (2005). Human cathelicidin antimicrobial peptide (CAMP) gene is a direct target of the vitamin $\mathrm{D}$ receptor and is strongly upregulated in myeloid cells by $1,25-$ dihydroxyvitamin D3. FASEB J. 19, 1067-1077.

González-Zorn, B., Senna, J. P., Fiette, L., Shorte, S., Testard, A., Chignard, M., Courvalin, P., and Grillot-Courvalin, C. (2005). Bacterial and host factors implicated in nasal carriage of methicillin-resistant Staphylococcus aureus in mice. Infect. Immun. 73, 1847-1851.

Gross, O., Thomas, C. J., Guarda, G., and Tschopp, J. (2011). The inflammasome: an integrated view. Immunol. Rev. 243, 136-151.

Grundmeier, M., Tuchscherr, L., Bruck, M., Viemann, D., Roth, J., Willscher, E., Becker, K., Peters, G., and Löffler, B. (2010). Staphylococcal strains vary greatly in their ability to induce an inflammatory response in endothelial cells. J. Infect. Dis. 201, 871-880.

Haim, M., Trost, A., Maier, C. J., Achatz, G., Feichtner, S., Hintner, H., Bauer, J. W., and Onder, K. (2010). Cytokeratin 8 interacts with clumping factor B: a new possible virulence factor target. Microbiology 156 3710-3721.

Hari, A., Flach, T. L., Shi, Y., and Mydlarski, P. R. (2010). Toll-like receptors: role in dermatological disease. Mediators Inflamm. 2010, 437246.

Hata, T. R., Kotol, P., Jackson, M., Nguyen, M., Paik, A., Udall, D., Kanada, K., Yamasaki, K., Alexandrescu, D., and Gallo, R. L. (2008). Administration of oral vitamin D induces cathelicidin production in atopic individuals. J. Allergy Clin. Immunol. 122, 829-831.

Heilmann, C. (2011). Adhesion mechanisms of staphylococci. Adv. Exp. Med. Biol. 715, 105-123.

Hiemstra, P. S., Maassen, R. J., Stolk, J., Heinzel-Wieland, R., Steffens, G. J., and Dijkman, J. H. (1996). Antibacterial activity of antileukoprotease. Infect. Immun. 64, 4520-4524. 
Holtfreter, S., Roschack, K., Eichler, P., Eske, K., Holtfreter, B., Kohler, C., Engelmann, S., Hecker, M., Greinacher, A., and Broker, B. M. (2006). Staphylococcus aureus carriers neutralize superantigens by antibodies specific for their colonizing strain: a potential explanation for their improved prognosis in severe sepsis. J. Infect. Dis. 193, 1275-1278.

Hruz, P., Zinkernagel, A. S., Jenikova, G., Botwin, G. J., Hugot, J. P., Karin, M., Nizet, V., and Eckmann, L. (2009). NOD2 contributes to cutaneous defense against Staphylococcus aureus through alpha-toxindependent innate immune activation. Proc. Natl. Acad. Sci. USA 106, 12873-12878.

Ip, W. K., Takahashi, K., Ezekowitz, R. A., and Stuart, L. M. (2009). Mannose-binding lectin and innate immunity. Immunol. Rev. 230, 9-21.

Iwase, T., Uehara, Y., Shinji, H., Tajima, A., Seo, H., Takada, K., Agata, T., and Mizunoe, Y. (2010). Staphylococcus epidermidis Esp inhibits Staphylococcus aureus biofilm formation and nasal colonization. Nature 465, 346-349.

Jensen, J. M., Folster-Holst, R., Baranowsky, A., Schunck, M., WinotoMorbach, S., Neumann, C., Schütze, S., and Proksch, E. (2004). Impaired sphingomyelinase activity and epidermal differentiation in atopic dermatitis. J. Invest. Dermatol. 122, 1423-1431.

Kartashova, O. L., Norkina, A. S., Chainikova, I. N., and Smoliagin, A. I. (2009). Phenotypic characteristic of staphylococci and local immunity during bacterial carriage. $Z h$. Mikrobiol. Epidemiol. Immunobiol. 4, 99-102.

Kemper, C., and Atkinson, J. P. (2007). T-cell regulation: with complements from innate immunity. Nat. Rev. Immunol. 7, 9-18.

Kezic, S., Kemperman, P. M., Koster, E. S., de Jongh, C. M., Thio, H. B., Campbell, L. E., Irvine, A. D., McLean, W. H., Puppels, G. J., and Caspers, P. J. (2008). Loss-offunction mutations in the filaggrin gene lead to reduced level of natural moisturizing factor in the stratum corneum. J. Invest. Dermatol. 128, 2117-2119.

Kisich, K. O., Carspecken, C. W., Fieve, S., Boguniewicz, M., and Leung, D. Y. (2008). Defective killing of Staphylococcus aureus in atopic dermatitis is associated with reduced mobilization of human beta-defensin-3. J. Allergy Clin. Immunol. 122, 62-68.

Kisich, K. O., Howell, M. D., Boguniewicz, M., Heizer, H. R., Watson,
N. U., and Leung, D. Y. (2007). The constitutive capacity of human keratinocytes to kill Staphylococcus aureus is dependent on beta-defensin 3. J. Invest. Dermatol. 127, 23682380.

Kluytmans, J., van Belkum, A., and Verbrugh, H. (1997). Nasal carriage of Staphylococcus aureus: epidemiology, underlying mechanisms, and associated risks. Clin. Microbiol. Rev. 10, 505-520.

Kluytmans, J. A., and Wertheim, H. F. (2005). Nasal carriage of Staphylococcus aureus and prevention of nosocomial infections. Infection 33, 3-8.

Krismer, B., and Peschel, A. (2011). Does Staphylococcus aureus nasal colonization involve biofilm formation? Future Microbiol. 6, 489-493.

Krut, O., Utermohlen, O., Schlossherr, X., and Kronke, M. (2003). Strainspecific association of cytotoxic activity and virulence of clinical Staphylococcus aureus isolates. Infect. Immun. 71, 2716-2723.

Kumar, H., Kawai, T., and Akira, S. (2009). Pathogen recognition in the innate immune response. Biochem. J. 420, 1-16.

Laarman, A., Milder, F., van, S. J., and Rooijakkers, S. (2010). Complement inhibition by Gram-positive pathogens: molecular mechanisms and therapeutic implications. J. Mol. Med. 88, 115-120.

Lai, Y., Cogen, A. L., Radek, K. A., Park, H. J., MacLeod, D. T., Leichtle, A., Ryan, A. F., Di Nardo, A., and Gallo, R. L. (2010). Activation of TLR2 by a small molecule produced by Staphylococcus epidermidis increases antimicrobial defense against bacterial skin infections. J. Invest. Dermatol. 130, 2211-2221.

Lai, Y., Di, N. A., Nakatsuji, T., Leichtle, A., Yang, Y., Cogen, A. L., Wu, Z. R., Hooper, L. V., Schmidt, R. R., von Aulock, S., Radek, K. A., Huang, C. M., Ryan, A. F., and Gallo, R. L. (2009). Commensal bacteria regulate Toll-like receptor 3-dependent inflammation after skin injury. Nat. Med. 15, 1377-1382.

Lambris, J. D., Ricklin, D., and Geisbrecht, B. V. (2008). Complement evasion by human pathogens. Nat. Rev. Microbiol. 6, 132-142.

Laudien, M., Gadola, S., Podschun, R., Hedderich, J., Paulsen, J., ReinholdKeller, E., Csernok, E., Ambrosch, P., Hellmich, B., Moosig, F., Gross, W., Sahly, H., and Lamprecht, P. (2010). Nasal carriage of Staphylococcus aureus and endonasal activity in Wegener's granulomatosis as compared to rheumatoid arthritis and chronic rhinosinusitis with nasal polyps. Clin. Exp. Rheumatol. 28, 51-55.

Lee, D. Y., Huang, C. M., Nakatsuji, T., Thiboutot, D., Kang, S. A., Monestier, M., and Gallo, R. L. (2009). Histone $\mathrm{H} 4$ is a major component of the antimicrobial action of human sebocytes. J. Invest. Dermatol. 129 2489-2496.

Lina, G., Boutite, F., Tristan, A., Bes, M., Etienne, J., and Vandenesch, F. (2003). Bacterial competition for human nasal cavity colonization: role of staphylococcal agr alleles. Appl. Environ. Microbiol. 69, $18-23$.

Lindsay, J. A., Moore, C. E., Day, N. P., Peacock, S. J., Witney, A. A., Stabler, R. A., Husain, S. E., Butcher, P. D., and Hinds, J. (2006). Microarrays reveal that each of the ten dominant lineages of Staphylococcus aureus has a unique combination of surfaceassociated and regulatory genes. J. Bacteriol. 188, 669-676.

Linzmeier, R., Ho, C. H., Hoang, B. V., and Ganz, T. (1999). A 450-kb contig of defensin genes on human chromosome 8p23. Gene 233, 205-211.

Lorenz, E., Mira, J. P., Cornish, K. L., Arbour, N. C., and Schwartz, D. A. (2000). A novel polymorphism in the toll-like receptor 2 gene and its potential association with staphylococcal infection. Infect. Immun. 68, 6398-6401.

Manenschijn, L., Jetten, A. M., van Wamel, W. J., Tavakol, M., Koper, J. W., van den Akker, E. L., van Belkum, A., and van Rossum, E. F. (2011). Long-term cortisol levels are not associated with nasal carriage of Staphylococcus aureus. Eur. J. Clin. Microbiol. Infect. Dis. 31, 97-100.

Margolis, E., Yates, A., and Levin, B. R. (2010). The ecology of nasal colonization of Streptococcus pneumoniae, Haemophilus influenzae and Staphylococcus aureus: the role of competition and interactions with host's immune response. BMC Microbiol. 10, 59. doi: 10.1186/1471-2180-10-59 Martinon, F., Mayor, A., and Tschopp J. (2009). The inflammasomes: guardians of the body. Annu. Rev. Immunol. 27, 229-265.

Matheson, E. M., Mainous, A. G., Hueston, W. J., Diaz, V. A., and Everett, C. J. (2010). Vitamin D and methicillinresistant Staphylococcus aureus nasal carriage. Scand. J. Infect. Dis. 42, 455-460.

McCarthy, A. J., and Lindsay, J. A. (2010). Genetic variation in Staphylococcus aureus surface and immune evasion genes is lineage associated: implications for vaccine design and host-pathogen interactions. BMC Microbiol. 10, 173. doi: 10.1186/1471-2180-10-173

Melles, D. C., Gorkink, R. F., Boelens, H. A., Snijders, S. V., Peeters, J. K., Moorhouse, M. J., van der Spek, P. J., van Leeuwen, W. B., Simons, G., Verbrugh, H. A., and van Belkum, A. (2004). Natural population dynamics and expansion of pathogenic clones of Staphylococcus aureus. J. Clin. Invest. 114, 1732-1740.

Mertz, D., Frei, R., Jaussi, B., Tietz, A. Stebler, C., Fluckiger, U., and Widmer, A. F. (2007). Throat swabs are necessary to reliably detect carriers of Staphylococcus aureus. Clin. Infect. Dis. 45, 475-477.

Miajlovic, H., Fallon, P. G., Irvine, A. D., and Foster, T. J. (2010). Effect of filaggrin breakdown products on growth of and protein expression by Staphylococcus aureus. J. Allergy Clin. Immunol. 126, 1184-1190.

Midorikawa, K., Ouhara, K., Komatsuzawa, H., Kawai, T., Yamada, S., Fujiwara, T., Yamazaki, K., Sayama, K., Taubman, M. A., Kurihara, H., Hashimoto, K., and Sugai, M. (2003). Staphylococcus aureus susceptibility to innate antimicrobial peptides, beta-defensins and CAP18, expressed by human keratinocytes. Infect. Immun. 71, 3730-3739.

Miller, L. S., and Cho, J. S. (2011). Immunity against Staphylococcus aureus cutaneous infections. Nat. Rev. Immunol. 11, 505-518.

Miller, L. S., O'Connell, R. M., Gutierrez, M. A., Pietras, E. M., Shahangian, A., Gross, C. E., Thirumala, A., Cheung, A. L., Cheng, G., and Modlin, R. L. (2006). MyD88 mediates neutrophil recruitment initiated by IL-1R but not TLR2 activation in immunity against Staphylococcus aureus. Immunity 24, 79-91.

Miller, L. S., Pietras, E. M., Uricchio, L. H., Hirano, K., Rao, S., Lin, H., O'Connell, R. M., Iwakura, Y., Cheung, A. L., Cheng, G., and Modlin, R. L. (2007). Inflammasomemediated production of IL-1beta is required for neutrophil recruitment against Staphylococcus aureus in vivo. J. Immunol. 179, 6933-6942.

Minegishi, Y., and Karasuyama, $\mathrm{H}$. (2009). Defects in Jak-STATmediated cytokine signals cause hyper-IgE syndrome: lessons from a primary immunodeficiency. Int. Immunol. 21, 105-112.

Moore, C. E., Segal, S., Berendt, A. R., Hill, A. V., and Day, N. P. (2004). Lack of association between Toll-like receptor 2 polymorphisms and susceptibility to severe disease caused by 
Staphylococcus aureus. Clin. Diagn. Lab. Immunol. 11, 1194-1197.

Moynagh, P. N. (2003). Toll-like receptor signalling pathways as key targets for mediating the anti-inflammatory and immunosuppressive effects of glucocorticoids. J. Endocrinol. 179, 139-144.

Murakami, M., Lopez-Garcia, B., Braff, M., Dorschner, R. A., and Gallo, R. L. (2004). Postsecretory processing generates multiple cathelicidins for enhanced topical antimicrobial defense. J. Immunol. 172, 3070-3077.

Muthukrishnan, G., Quinn, G. A., Lamers, R. P., Diaz, C., Cole, A. L., Chen, S., and Cole, A. M. (2011). Exoproteome of Staphylococcus aureus reveals putative determinants of nasal carriage. J. Proteome Res. 10, $2064-$ 2078.

Nakatsuji, T., Kao, M. C., Fang, J. Y., Zouboulis, C. C., Zhang, L., Gallo, R. L., and Huang, C. M. (2009). Antimicrobial property of lauric acid against Propionibacterium acnes: its therapeutic potential for inflammatory acne vulgaris. J. Invest. Dermatol. 129, 2480-2488.

Nestle, F. O., Di, M. P., Qin, J. Z., and Nickoloff, B. J. (2009). Skin immune sentinels in health and disease. Nat. Rev. Immunol. 9, 679-691.

Nilsen, N. J., Deininger, S., Nonstad, U., Skjeldal, F., Husebye, H., Rodionov, D., von Aulock, S., Hartung, T., Lien, E., Bakke, O., and Espevik, T. (2008). Cellular trafficking of lipoteichoic acid and Toll-like receptor 2 in relation to signaling: role of CD14 and CD36. J. Leukoc. Biol. 84, 280-291.

O’Brien, L. M., Walsh, E. J., Massey, R. C., Peacock, S. J., and Foster, T. J. (2002). Staphylococcus aureus clumping factor $\mathrm{B}(\mathrm{ClfB})$ promotes adherence to human type I cytokeratin 10: implications for nasal colonization. Cell. Microbiol. 4, 759-770.

Ochs, H. D., Oukka, M., and Torgerson, T. R. (2009). TH17 cells and regulatory $\mathrm{T}$ cells in primary immunodeficiency diseases. J. Allergy Clin. Immunol. 123, 977-983.

Olsen, K., Falch, B. M., Danielsen, K., Johannessen, M., Ericson Sollid, J. U., Thune, I., Grimnes, G., Jorde, R., Simonsen, G. S., and Furberg, A. S. (2011). Staphylococcus aureus nasal carriage is associated with serum 25hydroxyvitamin D levels, gender and smoking status. The Tromso Staph and Skin Study. Eur. J. Clin. Microbiol. Infect. Dis. 31, 465-473.

Olsen, K., Simonsen, G. S., Sundsfjord, A., Haukland, H. H., Sollid, J. E., Danielsen, K., Haldorsen, B., Eggen,
A. E., and Furberg, A. S. (2009). "The epidemiology of Staphylococcus aureus nasal and throat carriage in a large community-based population in North Norway. The Tromsø Staph and Skin Study," in 19th European Congress of Clinical Microbiology and Infectious Diseases, Helsinki, 16-19 May 2009.

Otto, M., Echner, H., Voelter, W., and Gotz, F. (2001). Pheromone cross-inhibition between Staphylococcus aureus and Staphylococcus epidermidis. Infect. Immun. 69, 1957-1960.

Palmer, C. N., Irvine, A. D., TerronKwiatkowski, A., Zhao, Y., Liao, H., Lee, S. P., Goudie, D. R., Sandilands, A., Campbell, L. E., Smith, F. J., O'Regan, G. M., Watson, R. M., Cecil, J. E., Bale, S. J., Compton, J. G., DiGiovanna, J. J., Fleckman, P., Lewis-Jones, S., Arseculeratne, G., Sergeant, A., Munro, C. S., El Houate, B., McElreavey, K., Halkjaer, L. B., Bisgaard, H., Mukhopadhyay, S., and McLean, W. H. (2006). Common loss-of-function variants of the epidermal barrier protein filaggrin are a major predisposing factor for atopic dermatitis. Nat. Genet. 38, 441-446.

Panierakis, C., Goulielmos, G., Mamoulakis, D., Maraki, S., Papavasiliou, E., and Galanakis, E. (2009). Staphylococcus aureus nasal carriage might be associated with vitamin $\mathrm{D}$ receptor polymorphisms in type 1 diabetes. Int. J. Infect. Dis. 13, e437-e443.

Picard, C., Casanova, J. L., and Puel, A. (2011). Infectious diseases in patients with IRAK-4, MyD88, NEMO, or IkappaBalpha deficiency. Clin. Microbiol. Rev. 24, 490-497.

Plouin-Gaudon, I., Clement, S., Huggler, E., Chaponnier, C., Francois, P., Lew, D., Schrenzel, J., Vaudaux, P., and Lacroix, J. S. (2006). Intracellular residency is frequently associated with recurrent Staphylococcus aureus rhinosinusitis. Rhinology 44, 249-254.

Proksch, E., Brandner, J. M., and Jensen, J. M. (2008). The skin: an indispensable barrier. Exp. Dermatol. 17, 1063-1072.

Pynnonen, M., Stephenson, R. E., Schwartz, K., Hernandez, M., and Boles, B. R. (2011). Hemoglobin promotes Staphylococcus aureus nasal colonization. PLoS Pathog. 7, e1002104. doi: 10.1371/journal. ppat.1002104

Quinn, G. A., and Cole, A. M. (2007). Suppression of innate immunity by a nasal carriage strain of Staphylococcus aureus increases its colonization on nasal epithelium. Immunology 122, 80-89.

Quinn, G. A., Tarwater, P. M., and Cole, A. M. (2009). Subversion of interleukin-1-mediated host defence by a nasal carrier strain of Staphylococcus aureus. Immunology 128, e222-e229.

Rieg, S., Garbe, C., Sauer, B., Kalbacher, H., and Schittek, B. (2004). Dermcidin is constitutively produced by eccrine sweat glands and is not induced in epidermal cells under inflammatory skin conditions. $\mathrm{Br}$. J. Dermatol. 151, 534-539.

Roche, F. M., Meehan, M., and Foster, T. J. (2003). The Staphylococcus aureus surface protein SasG and its homologues promote bacterial adherence to human desquamated nasal epithelial cells. Microbiology 149, 2759-2767.

Ruimy, R., Angebault, C., Djossou, F., Dupont, C., Epelboin, L., Jarraud, S., Lefevre, L. A., Bes, M., Lixandru, B. E., Bertine, M., El Miniai, A., Renard, M., Bettinger, R. M., Lescat, M., Clermont, O., Peroz, G., Lina, G., Tavakol, M., Vandenesch, F., van Belkum, A., Rousset, F., and Andremont, A. (2010). Are host genetics the predominant determinant of persistent nasal Staphylococcus aureus carriage in humans? J. Infect. Dis. 202, 924-934.

Sakwinska, O., Kuhn, G., Balmelli, C., Francioli, P., Giddey, M., Perreten, V., Riesen, A., Zysset, F., Blanc, D. S., and Moreillon, P. (2009). Genetic diversity and ecological success of Staphylococcus aureus strains colonizing humans. Appl. Environ. Microbiol. $75,175-183$

Sangvik, M., Olsen, R. S., Olsen, K., Simonsen, G. S., Furberg, A. S., and Sollid, J. U. (2011). Age- and genderassociated Staphylococcus aureus spa types found among nasal carriers in a general population. The Tromso Staph and Skin Study. J. Clin. Microbiol. 49, 4213-4218.

Schaffer, A. C., Solinga, R. M., Cocchiaro, J., Portoles, M., Kiser, K. B., Risley, A., Randall, S. M., Valtulina, V., Speziale, P., Walsh, E., Foster, T., and Lee, J. C. (2006). Immunization with Staphylococcus aureus clumping factor B, a major determinant in nasal carriage, reduces nasal colonization in a murine model. Infect. Immun. 74, 2145-2153.

Schauber, J., Dorschner, R. A., Coda, A. B., Buchau, A. S., Liu, P. T., Kiken, D., Helfrich, Y. R., Kang, S., Elalieh, H. Z., Steinmeyer, A., Zügel, U., Bikle, D. D., Modlin, R. L., and Gallo, R. L. (2007). Injury enhances TLR2 function and antimicrobial peptide expression through a vitamin $\mathrm{D}$-dependent mechanism. $J$. Clin. Invest. 117, 803-811.

Schauber, J., and Gallo, R. L. (2009). Antimicrobial peptides and the skin immune defense system. J. Allergy Clin. Immunol. 124, R13-R18.

Schauber, J., Oda, Y., Buchau, A. S., Yun, Q. C., Steinmeyer, A., Zügel, U., Bikle, D. D., and Gallo, R. L. (2008). Histone acetylation in keratinocytes enables control of the expression of cathelicidin and CD14 by 1,25 dihydroxyvitamin D3. J. Invest. Dermatol. 128, 816-824.

Scholzen, T., and Gerdes, J. (2000). The Ki-67 protein: from the known and the unknown. J. Cell. Physiol. 182, 311-322.

Secor, P. R., James, G. A., Fleckman, P., Olerud, J. E., McInnerney, K., and Stewart, P. S. (2011). Staphylococcus aureus biofilm and planktonic cultures differentially impact gene expression, MAPK phosphorylation, and cytokine production in human keratinocytes. BMC Microbiol. 11, 143. doi: 10.1186/14712180-11-143

Selva, L., Viana, D., Regev-Yochay, G., Trzcinski, K., Corpa, J. M., Lasa, I., Novick, R. P., and Penadés, J. R. (2009). Killing niche competitors by remote-control bacteriophage induction. Proc. Natl. Acad. Sci. U.S.A. 106 1234-1238.

Sharp, J. A., and Cunnion, K. M. (2010). Disruption of the alternative pathway convertase occurs at the staphylococcal surface via the acquisition of factor $\mathrm{H}$ by Staphylococcus aureus. Mol. Immunol. 48, 683-690.

Simpson, A. J., Maxwell, A. I., Govan, J. R., Haslett, C., and Sallenave, J. M. (1999). Elafin (elastase-specific inhibitor) has anti-microbial activity against gram-positive and gramnegative respiratory pathogens. FEBS Lett. 452, 309-313.

Sinha, B., and Fraunholz, M. (2010). Staphylococcus aureus host cell invasion and post-invasion events. Int. J. Med. Microbiol. 300, 170-175.

Siod, M., and Fløisand, Y. (2009). NOD2/CARD15 on bone marrow CD34+ hematopoietic cells mediates induction of cytokines and cell differentiation. J. Leukoc. Biol. 85, 939-946.

Tait, A. S., Butts, C. L., and Sternberg, E. M. (2008). The role of glucocorticoids and progestins in inflammatory, autoimmune, and infectious disease. J. Leukoc. Biol. 84, 924-931.

Tajima, A., Iwase, T., Shinji, H., Seki, K., and Mizunoe, Y. (2009). Inhibition of endothelial interleukin-8 
production and neutrophil transmigration by Staphylococcus aureus beta-hemolysin. Infect. Immun. 77, 327-334.

Tajima, A., Seki, K., Shinji, H., and Masuda, S. (2007). Inhibition of interleukin- 8 production in human endothelial cells by Staphylococcus aureus supernatant. Clin. Exp. Immunol. 147, 148-154.

Takeuchi, O., Hoshino, K., and Akira, S. (2000). Cutting edge: TLR2-deficient and MyD88-deficient mice are highly susceptible to Staphylococcus aureus infection. J. Immunol. 165, 53925396.

Takigawa, H., Nakagawa, H., Kuzukawa, M., Mori, H., and Imokawa, G. (2005). Deficient production of hexadecenoic acid in the skin is associated in part with the vulnerability of atopic dermatitis patients to colonization by Staphylococcus aureus. Dermatology 211, 240-248.

Ten Broeke-Smits, N. J., Kummer, J. A., Bleys, R. L., Fluit, A. C., and Boel, C. H. (2010). Hair follicles as a niche of Staphylococcus aureus in the nose; is a more effective decolonisation strategy needed? J. Hosp. Infect. 76, 211-214

Tong, S. Y., Chen, L. F., and Fowler, V. G. Jr. (2012). Colonization, pathogenicity, host susceptibility, and therapeutics for Staphylococcus aureus: what is the clinical relevance? Semin. Immunopathol. 34, 185-200.

Toth, B. I., Olah, A., Szollosi, A. G., Czifra, G., and Biro, T. (2011). "Sebocytes' makeup": novel mechanisms and concepts in the physiology of the human sebaceous glands. Pflugers Arch. 461, 593-606.

Turner, M. W. (2003). The role of mannose-binding lectin in health and disease. Mol. Immunol. 40, 423-429.

Turvey, S. E., and Broide, D. H. (2010). Innate immunity. J. Allergy Clin. Immunol. 125, S24-S32.

Uehara, Y., Kikuchi, K., Nakamura, T., Nakama, H., Agematsu, K., Kawakami, Y., Maruchi, N., and Totsuka, K. (2001). H(2)O(2) produced by viridans group streptococci may contribute to inhibition of methicillin-resistant Staphylococcus aureus colonization of oral cavities in newborns. Clin. Infect. Dis. 32, 1408-1413.

Uehara, Y., Nakama, H., Agematsu, K., Uchida, M., Kawakami, Y., Abdul Fattah, A., and Maruchi, N. S. (2000). Bacterial interference among nasal inhabitants: eradication of Staphylococcus aureus from nasal cavities by artificial implantation of Corynebacterium sp. J. Hosp. Infect. 44, 127-133. van Belkum, A. (2011). Novel technology to study co-evolution of humans and Staphylococcus aureus: consequences for interpreting the biology of colonisation and infection. $A d v$. Exp. Med. Biol. 697, 273-288.

van Belkum, A., Emonts, M., Wertheim, H., de, J. C., Nouwen, J., Bartels, H., Cole, A, Cole, A., Hermans, P., Boelens, H., Toom, N. L., Snijders, S., Verbrugh, H., and van Leeuwen, W. (2007). The role of human innate immune factors in nasal colonization by Staphylococcus aureus. Microbes Infect. 9, 1471-1477.

van Belkum, A., Verkaik, N. J., de Vogel, C. P., Boelens, H. A., Verveer, J., Nouwen, J. L., Verbrugh, H. A., and Wertheim, H. F. (2009). Reclassification of Staphylococcus aureus nasal carriage types. J. Infect. Dis. 199, 1820-1826.

van den Akker, E. L., Nouwen, J. L., Melles, D. C., van Rossum, E. F., Koper, J. W., Uitterlinden, A. G., Hofman, A., Verbrugh, H. A., Pols, H. A., Lamberts, S. W., and van Belkum, A. (2006). Staphylococcus aureus nasal carriage is associated with glucocorticoid receptor gene polymorphisms. J. Infect. Dis. 194, 814-818.

van Rijen, M. M., Bonten, M., Wenzel, R. P., and Kluytmans, J. A. (2008). Intranasal mupirocin for reduction of Staphylococcus aureus infections in surgical patients with nasal carriage: a systematic review. J. Antimicrob. Chemother. 61, 254-261.

Verkaik, N. J., de Vogel, C. P., Boelens, H. A., Grumann, D., Hoogenboezem, T., Vink, C., Hooijkaas, H., Foster, T. J., Verbrugh, H. A., van Belkum, H., and van Wamel, W. J. (2009a). Anti-staphylococcal humoral immune response in persistent nasal carriers and noncarriers of Staphylococcus aureus. J. Infect. Dis. 199, 625-632.

Verkaik, N. J., Lebon, A., de Vogel, C. P., Hooijkaas, H., Verbrugh, H. A., Jaddoe, V. W., Hofman, A., Moll, H. A., van Belkum, A., and van Wamel, W. J. (2009b). Induction of antibodies by Staphylococcus aureus nasal colonization in young children. Clin. Microbiol. Infect. 16, 1312-1317.

von Eiff, C., Becker, K., Machka, K., Stammer, H., and Peters, G. (2001a). Nasal carriage as a source of Staphylococcus aureus bacteremia. Study Group. N. Engl. J. Med. 344, 11-16.

von Eiff, C., Becker, K., Metze, D., Lubritz, G., Hockmann, J., Schwarz, T., and Peters, G. (2001b). Intracellular persistence of Staphylococcus aureus small-colony variants within keratinocytes: a cause for antibiotic treatment failure in a patient with Darier's disease. Clin. Infect. Dis. 32, 1643-1647.

Voss, E., Wehkamp, J., Wehkamp, K., Stange, E. F., Schroder, J. M., and Harder, J. (2006). NOD2/CARD15 mediates induction of the antimicrobial peptide human beta-defensin- 2 . J. Biol. Chem. 281, 2005-2011.

Vuononvirta, J., Toivonen, L., Grondahl-Yli-Hannuksela, K. Barkoff, A. M., Lindholm, L., Mertsola, J., Peltola, V., and He, Q. (2011). Nasopharyngeal bacterial colonization and gene polymorphisms of mannose-binding lectin and toll-like receptors 2 and 4 in infants. PLoS ONE 6, e26198. doi: 10.1371/journal. pone.0026198

Wang, T. T., Nestel, F. P., Bourdeau, V., Nagai, Y., Wang, Q., Liao, J., TaveraMendoza, L., Lin, R., Hanrahan, J. W., Mader, S., and White, J. H. (2004) Cutting edge: 1,25-dihydroxyvitamin D3 is a direct inducer of antimicrobial peptide gene expression. J. Immunol. 173, 2909-2912.

Weber, G., Heilborn, J. D., Chamorro Jimenez, C. I., Hammarsjo, A., Torma, H., and Stahle, M. (2005). Vitamin D induces the antimicrobial protein hCAP18 in human skin. J. Invest. Dermatol. 124, 1080-1082.

Weidenmaier, C., Kokai-Kun, J. F., Kulauzovic, E., Kohler, T., Thumm, G., Stoll, H., Götz, F., and Peschel, A. (2008). Differential roles of sortaseanchored surface proteins and wall teichoic acid in Staphylococcus aureus nasal colonization. Int. J. Med. Microbiol. 298, 505-513.

Wertheim, H. F., Verveer, J., Boelens, H. A., van, B. A., Verbrugh, H. A., and Vos, M. C. (2005). Effect of mupirocin treatment on nasal, pharyngeal, and perineal carriage of Staphylococcus aureus in healthy adults. Antimicrob. Agents Chemother. 49, 1465-1467.

Wertheim, H. F., Vos, M. C., Ott, A., van Belkum, A., Kluytmans, J. A., van Keulen, P. H., VandenbrouckeGrauls, C. M., Meester, M. H., and Verbrugh, H. A. (2004). Risk and outcome of nosocomial Staphylococcus aureus bacteraemia in nasal carriers versus non-carriers. Lancet 364 , 703-705.

Wertheim, H. F., Walsh, E., Choudhurry, R., Melles, D. C., Boelens, H. A., Miajlovic, H., Verbrugh, H. A., Foster, T., and van Belkum, A. (2008). Key role for clumping factor B in Staphylococcus aureus nasal colonization of humans. PLoS Med. 5, el7. doi: 10.1371/journal.pmed.0050017 Wiesner, J., and Vilcinskas, A. (2010). Antimicrobial peptides: the ancient arm of the human immune system. Virulence 1, 440-464.

Wille, J. J., and Kydonieus, A. (2003). Palmitoleic acid isomer (C16:1delta6) in human skin sebum is effective against gram-positive bacteria. Skin Pharmacol. Appl. Skin Physiol. 16, 176-187.

Witney, A. A., Marsden, G. L., Holden, M. T., Stabler, R. A., Husain, S. E., Vass, J. K., Butcher, P. D., Hinds, J., and Lindsay, J. A. (2005). Design, validation, and application of a seven-strain Staphylococcus aureus PCR product microarray for comparative genomics. Appl. Environ. Microbiol. 71, 7504-7514.

Wos-Oxley, M. L., Plumeier, I., von, E. C., Taudien, S., Platzer, M., VilchezVargas, R., Becker, K., and Pieper, D. H. (2010). A poke into the diversity and associations within human anterior nare microbial communities. ISME J. 4, 839-851.

Yamasaki, K., and Gallo, R. L. (2008). Antimicrobial peptides in human skin disease. Eur. J. Dermatol. 18, 11-21.

Yang, D., Chen, Q., Hoover, D. M., Staley, P., Tucker, K. D., Lubkowski, J., and Oppenheim, J. J. (2003). Many chemokines including CCL20/MIP3alpha display antimicrobial activity. J. Leukoc. Biol. 74, 448-455.

Zanger, P., Holzer, J., Schleucher, R., Scherbaum, H., Schittek, B., and Gabrysch, S. (2010). Severity of Staphylococcus aureus infection of the skin is associated with inducibility of human beta-defensin 3 but not human beta-defensin 2. Infect. Immun. 78, 3112-3117.

Zanger, P., Holzer, J., Schleucher, R., Steffen, H., Schittek, B., and Gabrysch, S. (2009). Constitutive expression of the antimicrobial peptide RNase 7 is associated with Staphylococcus aureus infection of the skin. J. Infect. Dis. 200, 1907-1915.

Zanger, P., Nurjadi, D., Vath, B., and Kremsner, P. G. (2011). Persistent nasal carriage of Staphylococcus aureus is associated with deficien induction of human $\{$ beta $\}$-defensin 3 after sterile wounding of healthy skin in vivo. Infect. Immun. 79, 2658-2662.

Zautner, A. E., Krause, M., Stropahl, G., Holtfreter, S., Frickmann, H., Maletzki, C., Krekemeyer, B., Pau, H. W., and Podbielski, A. (2010). Intracellular persisting Staphylococcus aureus is the major pathogen in recurrent tonsillitis. PLoS ONE 5, e9452. doi: 10.1371/journal.pone.0009452

Zeerleder, S. (2011). C1-inhibitor: more than a serine protease inhibitor. Semin. Thromb. Hemost. 37, 362-374. 
Conflict of Interest Statement: The authors declare that the research was conducted in the absence of any commercial or financial relationships that could be construed as a potential conflict of interest.
Received: 24 February 2012; accepted: 10 April 2012; published online: 04 May 2012

Citation: Johannessen M, Sollid JE and Hanssen A-M (2012) Host and microbe determinants that may influence the success of S. aureus colonization. Front. Cell. Inf. Microbio. 2:56. doi: 10.3389/fcimb.2012.00056

Copyright (c) 2012 Johannessen, Sollid and Hanssen. This is an open-access article distributed under the terms of the Creative Commons Attribution Non Commercial License, which permits noncommercial use, distribution, and reproduction in other forums, provided the original authors and source are credited. 